\title{
Toward Sustainable Preservation of Cultural Heritage Buildings: A Combination of Digital Mapping and Architectural mapping for Omah Pencu in the Historic Area of Kudus Kulon
}

\author{
Atiek Suprapti ${ }^{1 *}$, Anang Wahyu Sejati ${ }^{2}$, Agung Budi Sardjono ${ }^{1}$, Edward E Pandelaki ${ }^{1}$, \\ Abdul Malik ${ }^{1}$, Nurma Mediasri Huwaida ${ }^{1}$ \\ ${ }^{1}$ Department of Architecture, Faculty of Engineering, Diponegoro University, \\ Jl. Prof. Soedarto, SH, Campus of UNDIP Tembalang, Semarang, Indonesia 50275 \\ ${ }^{2}$ Department of Urban and Regional Planning, Faculty of Engineering, Diponegoro University, \\ Jl. Prof. Soedarto, SH, Campus of UNDIP Tembalang, Semarang, Indonesia 50275
}

\begin{abstract}
This study aims to map the existence of the wooden houses of Omah Pencu and classifies their potencies as heritage buildings in the historic area of Kudus Kulon. Caring for indigenous cultural heritage will contribute to the strengthening of local identity. The traditional houses of Omah Pencu have been developing as the specific architecture since the end of the 17'th century, as a living place of the 'Gusjigang' community, and artifacts evident of the city heyday. However, the pressure of modernizationcapitalization in the city caused several changes in their built environment and decreased the number of Omah Pencu. This research concern with the GIS interpretation methods and the direct observations use the questionnaire, interview, and architectural documentation. The findings provide an important database for preservation in the digital era. The digital mapping, combined with the mapping of tangible and intangible buildings, produces digital information about the Omah Pencu building condition that has never been done before. Through this mapping, found that the participation effort of the community caused the sustainability of preservation. It is a very significant bottom-up participation. However, toward sustainable preservation, a strategy, planning, design, and management that integrated all stakeholders and resources by utilizing digital technology are needed.
\end{abstract}

Keywords: mapping; living heritage; preservation; Omah Pencu; community

\section{Introduction}

\section{The urgency of cultural heritage preservation}

One of the significant issues in recent decades associated with globalization is cultural identity. It is also mentioned in the 2016 New Urban Agenda relate to the importance of cultural diversity. Cultural heritage issue is increasingly becoming a consideration in world urban development. Cultural identity is an important part of a place's power (Hayden, 1995). It is a factor most vulnerable eroded by market forces and the global sphere (Budihardjo \& Sujarto, 1998; Catanese \& Snyder, 1979; Rapoport, 1997; Trancik, 1986), and they highlight the importance of socio-cultural aspects in the character formation of architectural space. Arefi (1999), Hayden (1995), and Ragusa (2017) in detail expressed

\footnotetext{
*) Corresponding author

E-mail: atiekbudiarto@gmail.com
}

the need of cultural history landscape to create a humanized place, in order to resolve the situation of 'placelessness'.

On the other hand, UNESCO launched the World Heritage program in 1950, which is intended to acknowledge and protect many cultural heritage expressions, sites, and practices (Caust \& Vecco, 2017). A good city is a city which able to allocate space for its history. It is needed to guarantee the development sustainability so that the generations will understand and appreciate their cultural heritage.

Managing cultural heritage needs good management. Good management of heritage sites will also benefit the tourism economy (De Bernardi, Bertello, \& Shams, 2019; Prompayuk \& Chairattananon, 2016; Suprapti et al., 2018). Management of cultural heritage sites includes a series of strategies, planning, design, and management that require collaboration involving stakeholders, government, community participation \& the private sector (La Frenierre, 2008). On the other hand, 


\section{TEKNIK, 41 (3), 2020, 202}

researchers in cultural policy and planning have advanced arguments supporting a culture's vision as a significant piece of life quality (Mercer, 2002). Once people are aware of the cultural resources in their community, integrated planning to maintain and improve community life quality becomes possible. Ghilardi (2001) also adopts an integrated approach to cultural assets. She refers to cultural resources and anything that contributes to a particular place or people's culture, whether it is tangible or intangible.

\section{The uniqueness of Omah Pencu as a work of Islamic architecture \\ Joglo house, which is found on the North Coast of} Java, has a different character from Joglo house in the Southern part of Java. This can be seen in the floor plan, construction, ornamentation, aesthetic arrangements, and the building's direction (Roesmanto, 2002). Kudus City, one of the old cities in Java's North Coast region that developed due to the spread of Islam, has a distinctive Joglo variant form known as the Omah Pencu. Omah Puncuis is a blend of joglo dan limasan forms resulting from acculturation between Hindu, Chinese, Islamic, and European cultures (Ekarini, 2016). This house uses gebyog walls (ornamental carved wood wall), then this building is better known as Omah Pencu.

Omah Pencu is a variant of the traditional Javanese house on the coast region. In the case a traditional Javanese house consists of the main building, namely dalem (main house), pringgitan (a place to see a shadow puppet show), pendopo (pavilion) and complementary buildings, namely: gandok (bedroom), gadri, pawon (kitchen), pekiwan (well and bathroom). According to Sardjono (2009) a pendopo (pavilion) is a building in the form of open space, no wall, located in front of dalem. Pendopo never found in the layout of the Kudus house. Meanwhile, pringgitan in Javanese traditional house is replaced by jogosatru with some differences. pringgitan is open room - no dividing walls found in a joglo house. Jogosatru is a closed wooden wall (gebyog) completed three doors and functions as a guest room. Gandhok in a Javanese house may be paired with pawon (building for kitchen) in the Kudus house which located on the right or left side of dalem (main building). Pawon connect tightly positioned in the dalem, while at Javanese house gandhok is made a distance from dalem. Gadri in Javanese houses was replaced with backsideof pawon. The functions of pawon, gandhok and gadri are actually similar to accommodate the family activity. Pekiwan or a bathroom with a well in a Javanese house is located behind dalem, while in the Kudus house located in the front side. Sisir is a workplace building in Kudus houses, but not found in Javanese houses. Jogan and senthong is the similar, but in Javanese house the middle senthong is called krobongan, which is still used offering to the ancestors and the Goddess Sri (fertility goddes), meanwhile, in the Kudus house it is called gedhongan used to pray or laying up treasures (see Figure 1). The house of Kudus was completed with a massive and high fence so that the house's appearance almost invisible except for the peak of the roof. The entrance is marked by a roofed regol (gate of the fence) with a door leaves. The daily condition of the door leaves is always closed. In Javanese regol houses usually have no leaf doors, instead, they are given a straight line. The yard of the Kudus house is located in the middle, the yard receives and directs visitors to jogosatru (guest room), the closed yard is limited to outsiders, serves to accommodate family's activities outside the dalem.

Omah Pencu has a deep meaning, especially in Islam's spread, and marks cultural acculturation in Kudus area (Suprapti et al., 2014). Not only does it function as a residence for the santri community (faithful Muslim), but the layout, structure, symbol of the building, and ornaments have been adapted to Islamic culture after being adopted from joglo building (Sardjono, Hardiman, \& Prianto, 2016). From the socio-cultural side, the Kudus Kulon community has a strong character known as "Gusjigang" community, means that people good in morals, good in reciting as well as in trading. It is related to the teaching by Sunan Kudus that has been applying to meet the balancing of worldly affairs and after world.

\section{Mapping Omah Pencu toward sustainable preservation.}

The cultural life of a community is about participation, celebration, identity, belonging to a community, and having a sense of place (Grogan, Mercer, \& Engwicht, 1995; Mercer, 2006). Within cultural development, there has been an increased recognition that cultural planning should operate in a broad and inclusive definition of culture, including both the tangibles and the intangible elements. This understanding has also led to concentrated attempts on cultural planners' part to adopt an integrated and strategic view of cultural assets (EC--European Commission, 2014).

Cultural mapping is defined as a systematic approach to identifying a community's cultural resources in order to describe and visualize them (Baeker, 2010). It begins with building and
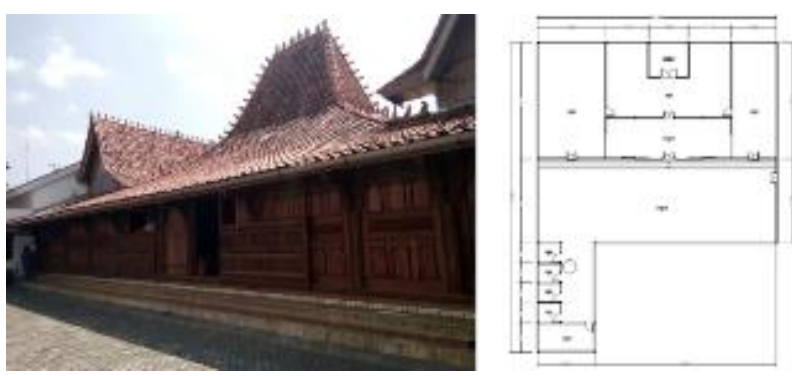

Figure 1 Omah Pencu with Pencu roof shape in Kudus Kulon 


\section{TEKNIK, 41 (3), 2020, 203}

maintaining a centralized database that helps to organize and communicate information. In other words, cultural planning is a tool that covers everything from groundbased research of participatory to sophisticated techniques of mapping by using the Geographic Information Systems (GIS). The UNESCO has also recognized this method in preserving the world's intangible and tangible cultural assets. This method also fosters collaboration across a wide range of stakeholders that can influence the political sphere and encourage suitable public policy-making. Understanding culture could be classified into two types of mapping (Baeker, 2010): asset mapping and community identity mapping.

The definition of cultural heritage moves through heritage values, involves more stakeholders in identifying these values, moves from building objects to landscapes, and currently includes tangible and intangible assets (Havinga, Colenbrander, \& Schellen, 2019). Mapping for the analysis of tangible and intangible aspects of cultural heritage is important. One of them uses the interpretative mapping method, which could be accomplished either a derivation from cartographic or an independent form of sense or impression (Hossain \& Barata, 2019). Meanwhile, digital mapping positions heritage as part of the big data and relates to the social web (Bonacchi \& Krzyzanska, 2019) for global use and access. The theoretical exploration and empirical conditions above remind the importance of mapping Omah Pencu in Kudus Kulon's historic area towards sustainable preservation. Therefore, this study aims to map the existence of Omah Pencu buildings in the Kudus Kulon historic area and classifies their potencies as a heritage building in the historic area of Kudus Kulon toward sustainable preservation, like architectural form and shape, detail of structure and ornaments, physical conditions, building age, and building functions.

\section{Research Method}

The area studied was the historical area of Kudus Kulon. It covers four villages, namely Langgardalem, Kauman, Kerjasan, and Damaran, where many Omah Pencu buildings are found. The research uses Geographic Information Systems (GIS) as tools and mapping platforms. This tool is combined with the architectural building identity mapping, exploring a community's 'intangible cultural resources relate to the omah pencu.

\subsection{Data Collecting}

The stage of Geographic Information Systems (GIS) mapping as tools and platforms includes: (1) base map making, (2) application designing to every data collection and data provision of omah pencu building, (3) Theme map making. (4) coordinate data plotting, (5) coordinate measurement data using a GPS device.

From the results of the GIS mapping, the building architectural data were inputted. For this reason, data collection was carried out by direct observation to obtain primary data through questionnaires and interviews.

The respondents' questionnaire was designed following the open questions model to make it possible for respondents to explain their reasons. The interview was done with the key informants, like government community figures and academicians who have a significant relation to the preservation of Omah Pencu. Interviews were conducted through the FGD forum. In this case, community participation has an important role in providing data and information. FGD is an effort to encourage significant community participation in conservation.

Building architectural data is obtained through secondary data, primary visual survey data with architectural documentation techniques, measurements, photos, videos, sketches, digital depictions, and interviews with residents. The Data included building quality, building completeness, roof shape, function, spatial function changes, and age. Further, those data were classified, categorized, and compared for discussion based on continuity and the community roles.

\subsection{Data Analysis}

The stages was started by analyzing and systematizing all the data from various sources, supporting literature, interviews, and field observation. The next step is to systematize the data by grouping it into predetermined variables. These groups are then presented in the forms of maps, patterns, percentages, or narratives.

The variable of building density can be identified by Quickbird Satellite imagery in time series versions. In analyzing the image, satellite image interpretation technique and GIS were used in order to test the validity of the accuracy of data interpretation results can be used as the basis of analysis and evaluation (Belgiu \& Drăgut, 2014; Cheng \& Han, 2016; Lillesand, Kiefer, \& Chipman, 2014; Wijaya et al., 2015). Results of interpretation that tested its accuracy are used to locate data building density and land-use change rate. Calculation of the building density is approached through a number of building basic coefficients per Building Coverage. Assessment of the building density coefficient is based on a comparison between the area of the building's ground floor with an area of land use of an area or region.

\subsection{Concluding the Findings}

After the analysis process complete, the next step is to conclude the research findings. This will be re-examined with the existing theory to obtain a research discovery.

\section{Result and Discussion \\ 3.1 Kudus Kulon Historic area}

The location of Kudus Kulon historic area is on the west side of the Gelis River (see Figure 2). By ethnicsociological, the traditional settlement in Kudus city is grouped by Gelis River's development, the oldest one of 


\section{TEKNIK, 41 (3), 2020, 204}

Kudus Kulon and the newest one of Kudus Wetan. In the early development (before 16's century), Kudus was a city on the Gelis River banks. The city was called Tajug, since there a lot of tajug (traditional architecture roof shape usually used for religious building) found in the area. These were the location of Hindus settlements. There were known two important figures in the city embodiment, namely Sunan Kudus, one of Walisanga members, and Kyai Telingsing, a religious leader from Yunan. Both of them have a mission to spread Islamic teaching. Sunan Kudus established a mixed-culture architectural minaret to complement the Al-Aqsa mosque. Then the name of Tajug replaced to be "Al-Quds" which means "holy", then known as "Kudus" until nowadays. The construction Al-Aqsa Mosque has characterized the establishment of Kudus.

In the front of the mosque was a large square marking the city center. This field is still present even though the remaining few that called Madureksan square. Kudus have grown in the same period of the development of Demak Sultanate. When the reign of Demak Sultanate collapsed then the power moved to the South-East area successively were Pajang and Mataram Sultanate. Under Mataram Sultanate, Kudus changed the economic orientation from coastal trading to land trading due to its strategic location. During the Dutch colonial occupation developed the new city in the East Gelis River, which was also characterized by a large mosque, Alun-alun (traditional city square), district government office, and marketplace. Good prosperity achieved by Kudus were appeared in the magnificent wooden houses, mosques, and in performing Hajj of the people. The Persian and European architecture has much decorated the ornamentation and the shape of the house. After the Independence Kudus developed into an industrial city, including the cigarette industry, paper industry, and electronic equipment industry. After reformation generally, the development of the city could be divided to be three which were: the old town known as Kudus Kulon area built by Sunan Kudus; the new city center in the Simpang Tujuh area, developed by the Dutch colonial government; and the commercial area in Jati area developed in the ' 80 an era and became a new center of trades and services.

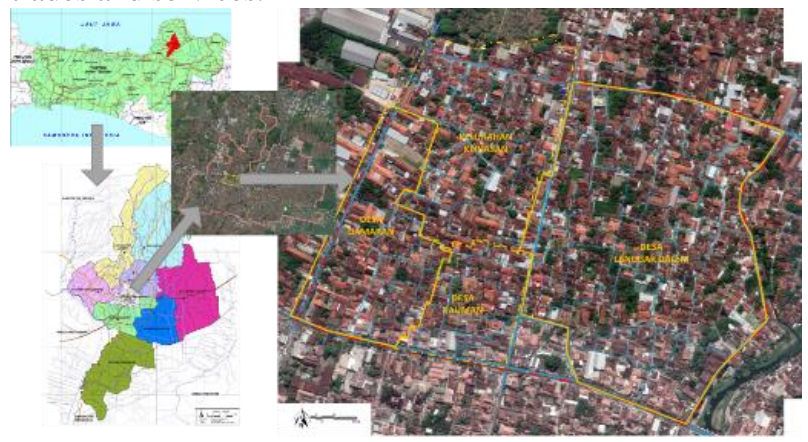

Figure 2 Research Location in Kudus Kulon Historic Area

\subsection{The role of stakeholders}

After the Reform, the Kudus Regency Government established the historic Kudus Kulon area as a strategic area and development priority in the socio-cultural field ( Kudus Spatial Plan 2012-2032). The primary function is to protect cultural heritage and cultural tourism. Omah Pencu in Kudus Kulon Historic area is the cultural heritage phenomenon protected by the cultural heritage ACT through the DECREE of the ancient relics No 988/102. SP/BP3/P. IX/2005 (Ekarini, 2016).

The government takes a role in maintaining and caring for the historic Kudus Kulon area through infrastructure development programs. The program includes public transport, bus stops, bus parking, parks, road networks, pedestrian paths, street vendors, etc. The proggram is intended to improve the environmental quality of the heritage monument of Al-Aqso Menara Kudus site. The government also encourages intangible assets in the form of local traditions to revive the area. However, the government efforts need to be synergized with other stakeholders to collaborate in a significant effort to maintain Omah Реnсu. Those discussions are in accordance with the statement by Havinga et al. (2019). The more stakeholders involved in management, the more they will encourage sustainability.

Kudus Kulon community has a significant role in maintaining and preserving the Omah Pencu building. Most of the residents are heirs and building owners who live together throughout history throughout the building's life. Tangible and intangible assets are reciprocally interconnected in living heritage (Blundo et al., 2018; Poulios, 2014). They tend to preserve the tradition of 'Gusjigang'. It is a local abbreviation that means people who have good morals, are good at reciting and are good at trading.

Declining economic conditions from the golden era, resulting in a different community's ability to care for Omah Pencu. The building's maintenance period can be once a year, once two years, once five years, even once in a decade, depending on the owners' financial conditions. According to residents, funding support from the government was launched once. Unfortunately, funding support from the government is not evenly distributed, so that not all residents get the funds.

The Foundation of Menara-Masjid is an NGO established to protect and care for the assets of Sunan Kudus. They concern for the maintenance and preservation by acquiring two buildings of Omah Pencu. The foundation takes care of the building and plans to be used as a museum. NGO members consist of the Al-Aqso mosque takmir (mosque manager), Kudus Kulon figures, the city government, academics and observers of cultural heritage buildings. However, there has not been any effort to encourage the formation of community organizations that 


\section{TEKNIK, 41 (3), 2020, 205}

recognize the need to protect and preserve Omah Реnсu in Kudus Kulon.

\subsection{Mapping of Omah Pencu}

Omah Pencu is a cultural heritage of Javanese architecture in Kudus. The Kudus traditional building has a different background from traditional Javanese houses in general in terms of roof shape, spatial organization, and spatial elements. The most prominent of Omah Pеnси is the shape of the pencu roof, which is higher and slightly tapered upwards (Ekarini, 2016; Roesmanto, 2002; Theresia, 2013; Wikantari, 2001). The original Kudus traditional house was originally only found in Kudus Kulon around the Menara Kudus Mosque, which later expanded. The development of the Omah Pencu was spearheaded by the Kudus merchants (Theresia, 2013). Kudus traditional house, whose condition is still seen today, has a joglo pencu roof and is decorated with the ornamental carved wood wall inside or outside the building.

Omah Pencu has been found at the time of mapping amounted to 50 units included in the research locus. Omah Pencu distribution can be seen in Figure 3. There are 5 houses in the Kelurahan Kerjasan, 6 houses in Damaran Village, 9 houses in Kauman Village, and 30 houses in Langgar Dalam Village (see Figure 3).

\subsection{Physical condition and completeness of the element}

Omah Pencu Kudus is a Kudus community culture that has unique characteristics (Rasyidi \& Amiuza, 2017). The primary material used in most traditional Kudus houses is wood carved with ornament. The ornamental carved wood can be found in front (jogosatru), inside (senthong \& gedhongan), and sideway building (pawon). Some houses even use the ornamental carved wood on the house's back side (Sardjono, 2009; Wikantari, 2001; Wikantari \& Narumi, 2001).

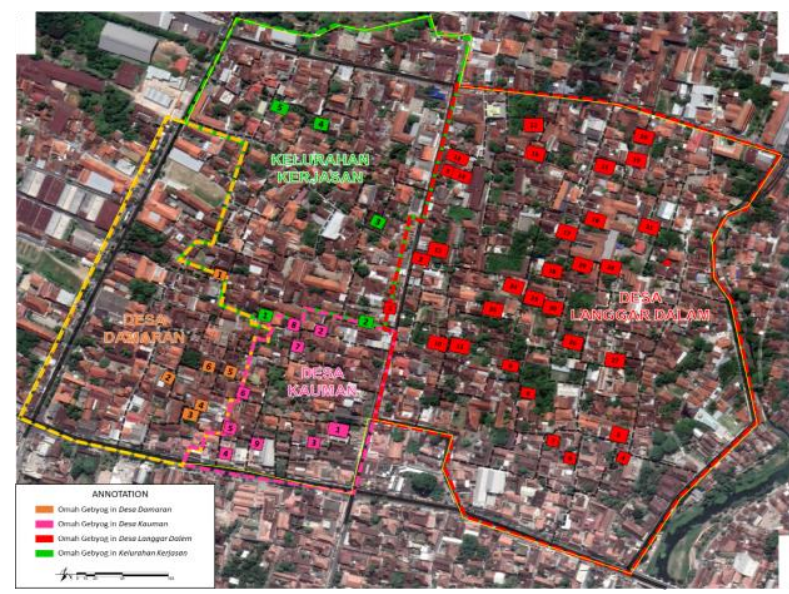

Figure 3 Mapping of Omah Pencu in Kudus Kulon
Due to the community's economic and sociocultural conditions, wood carvings and parts of houses from traditional houses undergo changes and adjustments to existing conditions. The building's physical condition will change due to limited material durability, especially in traditional homes. At this time, Omah Pencu was rarely found. Some buildings are lost because they have been sold, while some changed because they are damaged. Some even have changed to the new models and materials. Based on the survey results, most Omah Pencu conditions are still well maintained even though wood carving has experienced weathering. Some houses look neglected, not inhabited, and change of materials.

Studying the physical conditions of 50 samples of Omah Pencu, we have the following result: 20 houses (39\%) were in good condition; 13 houses $(25 \%)$ were in good enough condition; 9 houses (18\%) were in not good condition; 1 house (2\%) are in poorly maintained condition, and 8 houses (16\%) are unknown, due to limited access (see Figure 4).

Building maintenance is a major problem in preserving cultural heritage buildings, including Omah Pencu. Although a decree for building protection has been issued by the head of the Central Java Ancient Javanese Heritage Preservation Center, the maintenance of complex wooden buildings requires special expertise. Such maintenance must be done by the community traditionally and regularly (routinely). The maintenance costs are considered quite expensive for the community; they have experienced many declines given the current economic conditions. For the wealthy residents, treatment is done 1-2 years. Some do maintenance once in 5 years, and some do not do maintenance for decades. Care funding assistance from the government, ever received by particular citizens/communities, has not been routinely given. Based on interviews with residents, the final funds were received about five years ago. Thus, a larger role from the government is needed to maintain the Отаh Реnсu building to be better maintained.

\subsection{Typology of Omah Pencu}

Typology is the study of groupings by type or type of equality of certain traits (Moneo, 1978; Tunçbaş, 2006). Oтаh Pепси Kudus can be typologized based on the shape of the roof of the building, the layout of the space, the usefulness, and the quality of Omah Pencu itself.

\subsubsection{Roof Shape}

Physically it can be seen the shape of the joglo roof of the traditional Kudus building is taller and slightly pointed upwards. There are differences in economic capacity and knowledge building by the occupants. Variations appear in the Omah Репси that are reflected in the building roof's shape. Omah Pencu roof can be categorized into four forms: kampung, limasan, joglo dan pencu roof. Thus, the different forms of Omah Pencu roofs 


\section{TEKNIK, 41 (3), 2020, 206}

are symbols of their owners' economic status (Wikantari \& Narumi, 1999).

The shape of joglo pencu roof is like the traditional Javanese house shape, but the top point of the roof is higher. Those who occupy these houses are usually nobles (Sardjono, 2009; Wikantari, 2001). Omah gebyog with limasan roof is usually used by owners who have a have a high enough stratum. Limasan roof shape has 2 categories: limasan menerus and limasan maligi, the difference is the shaded area. limasan menerus combines the roof between the dalem area and the pawon area. The roof shape of limasan maligi in the dalem and pawon area in contrasts (Sardjono, 2009, 2011; Suprapti, 2014). Limasan maligi roof shape is the development from limasan roof shape, including an additional sloping roof at the front and back area. House with kampung roof shape is an ordinary people's house with a balanced roof shape between its left and right sides. The roof of the panggang pe house is the simplest compared to the others because it is only a onesided sloping roof, usually used as a residence and a shop.

The roof's shape still used only leaves 3 shapes, namely the roof of joglo pencu, limasan and limasan maligi (separated pawon-limasan). Most of the Omah Pencu use the pencu roof. The research findings show that $82 \%$ (41 houses) have the pencu roof type, while $6 \%$ (3 houses) have limasan roof, $2 \%$ (1 house) have limasan maligi roof, and $10 \%$ (5 houses) are unknown due to limited access (see
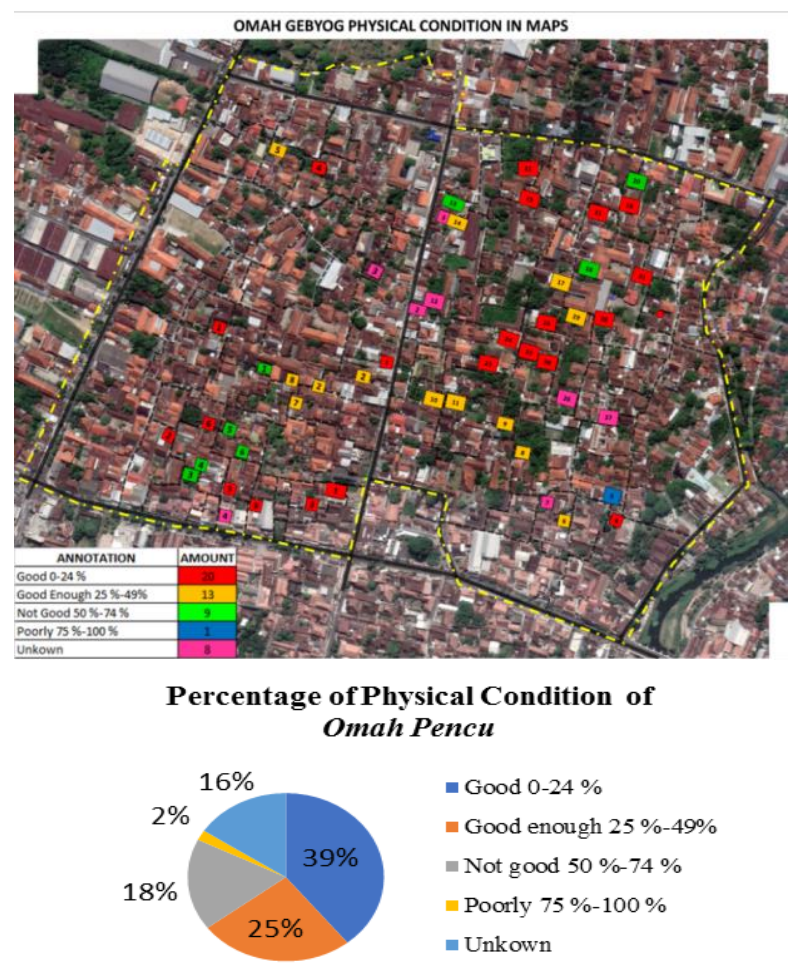

Figure 4 Physical Condition of Omah Pencu
Figure 5). The shape of the Omah Pencu roof is the most recognizable physical feature and shows its authenticity. The roof is the part that is most stable or difficult to change. This quantity data shows the economic triumph of that time. However, the current economic condition has been declining due to the political changes after the Indonesian Freedom. The decline affects building maintenance.

The shape of the pencu roof is a typical architectural work of the North Javanese coast, which is only found in Kudus, Demak, and Jepara. The specific roof shape contains cultural values that have contributed to the identity of the Kudus traditional house.

\subsubsection{Spatial layout}

The space division system in the traditional Kudus residence includes the main building, an open yard (latar), and complementary buildings (Sardjono, 2009). The main building Omah Pеnси Kudus always faces towards the south. The main building serves as a container for residents' main activities in the house, consisting of dalem, jogosatru and pawon. An open yard (latar) is an important part that functions to bind the form between a building and its surroundings. Sometimes the yard is a linkage between houses that make up the hallway and is used for roads. Complementary buildings are used to accommodate service activities and residents' economic activities. There are sometimes of well, bathroom and sisir (work place). Sisir is one that not all of Omah Pencu have.

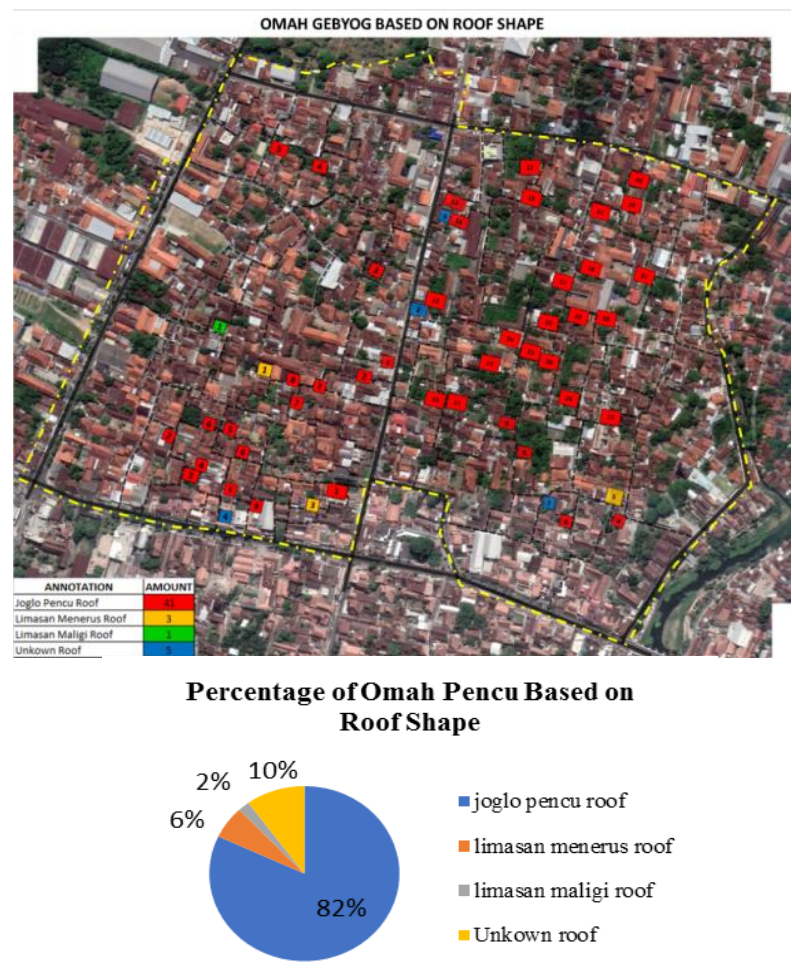

Figure 5 Mapping and Percentage Typology Omah Pencu based on Roof Shape 


\section{TEKNIK, 41 (3), 2020, 207}

Based on research findings, the diversity of spatial layout of Omah Pencu classified into four categories: (1) the main building without pawon, (2) the Pawon (main building) with one pawon, (3) the main building with two pawon, and (4) the main building with pawon and sisir. The type of Omah Pencu of main building with one pawon divided into two categories based on the location of the pawon on the left side or the right side. Omah Pencu classified as the main building with pawon and sisir divided into three categories based on the shape of sisir. Most Omah Pеncu layouts are the main building with a single wasp due to the community's economic condition. The research result shows that $36 \%$ (18 houses) are the main buildings with one pawon, $18 \%$ (9 houses) are main buildings with two pawon, 18\% (9 houses) are the main buildings with pawon, $14 \%$ (7 houses) are the main buildings without pawon, while 14\% (7 houses) are categorized as others (see Figure 6).

Omah Pencu's spatial complexity shows specific architectural features. This also shows the surplus financial of the residents who were built Omah Pencu at that time. However, after the Indonesian Freedom, the economic conditions changed. Many residents suffer from financial problems. Thus, they were tempted to sell these wooden houses, due to the high price. Following the local inheritance system, a building can be distributed to the heirs, based on the parts of the building. Such system allows each of the heirs gets each part of the building of Omah Pencu. This causes different changes in the house of Omah Pencu.

\subsubsection{Usability}

Based on research findings, the functions of Omah Pencu is classified into four categories: (1) the function of a house/ dwelling, (2) stalls/ business shops/ storage, (3) pesantren (religious education), and (4) museums. Most of the functions of Omah Pencu are for homes or residences. Research findings show that $78 \%$ (38 buildings) are used for home, $10 \%$ are used for stall/ business shop/storage, $8 \%$ are used for pesantren (religious boarding school), while $4 \%$ are used for museums (see Figure 7).

The function's dominance as a residence shows its original function, and all residents are descendants of the building's founders. This phenomenon is reminiscent of the concept of living heritage. Living heritage can be seen as a heritage site that retains its original function, which reflects the culture, the process of spatial definition as a form of response to changing circumstances in society (Poulios, 2010; Rashid, 2015). Omah Pencu, which has been mostly a dwelling, is a form of living heritage that still maintains traditional culture for generations. A change in function as a commercial one is an owner's response to changing needs and economics. Whereas changing the function from housing to a religious boarding school shows that the community's quality of Islamic culture is maintained well.

\subsubsection{Quality}

Based on research findings, the quality of the Omah Pencu is classified into four categories: (1) high quality (excellent), (2) good quality, (3) low quality, and (4) poor quality.

The high quality of Omah Pencu is the quality of house with full and intact ornamental wood carvings on the outer \& inner walls, structures, doors, and windows. The excellent quality of Отаһ Репси is a house with ornamental wood carvings only on the front wall, structure, doors, and windows. The low quality of Omah Pencu in the lowquality category only has engraving on particular elements such as doors, windows, and structures. The category also applied to Omah Pencu that has been modified and has no carving at all.

Most of Omah Pencu indicate that the house has quite good quality. $27 \%$ (12 houses) are classified as highquality gebyog, while $49 \%$ (22 houses) are maintained in good quality, $15 \%$ (7 houses) are in low quality, and $9 \%$ (4 houses) in low quality and not maintained (see figure 8). These data show that there are still preservation efforts by the community and owner despite the uneven distribution of Omah Pencu treatment funds. It is in line with the statement from Wikantari (1999).

\subsection{Toward sustainable preservation of 'Omah Pencu'}

The results of the discussion above shows that several aspects need attention towards the preservation of Omah Pencu in the historical area of Kudus Kulon:

Integrated management is needed to preserve Omah Pencu between various stakeholders, the communities, NGO, academics, carpenters, the public sector, and private sector. Implementing government policies to protect $\mathrm{Omah}$ Pencu with legislation from the Cultural Heritage Institution is an appropriate step. However, technical steps are needed for implementing the policy to involve both public and private sector participation. This result is similar to the opinions conveyed by Absalyamov, (2015), Prompayuk \& Chairattananon (2016), and Suprapti et al. (2017).

Community participation is a potential asset, the tangible \& intangible assets of Omah Репси in Kudus Kulon historic area is a living heritage that is an inseparable part. Gusjigang community has an important role in conservation efforts, both tangible and intangible. This is following Prompayuk \& Chairattananon's (2016) and Poulios's (2014). However, the changing of community economic not allow to support the building maintenance efforts. According to (Absalyamov, 2015), supports from public sector and private sector partnership are needed.

Comprehensive planning \& design that links tangible assets \& intangible assets, starting with data collection of architecture, environment, infrastructure, and management assets, is needed. It refers to the point of view of Stapleton et al. (2019). Inline with that above, Oikonomopoulou et al. (2017) convey that digitalization of technology is needed to support the preservation efforts. 


\section{TEKNIK, 41 (3), 2020, 208}

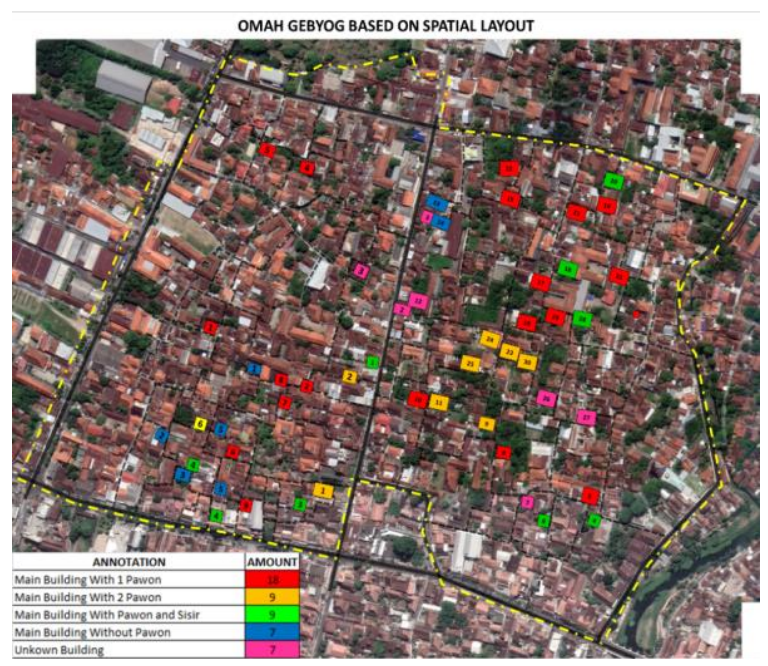

Percentage of Omah Pencu Based on Spatial Layout

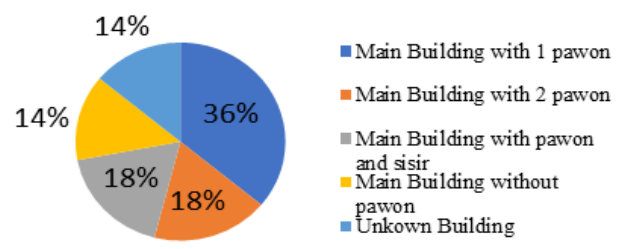

Figure 6 Mapping and Percentage Typology Omah Pencu based on Spatial Layout

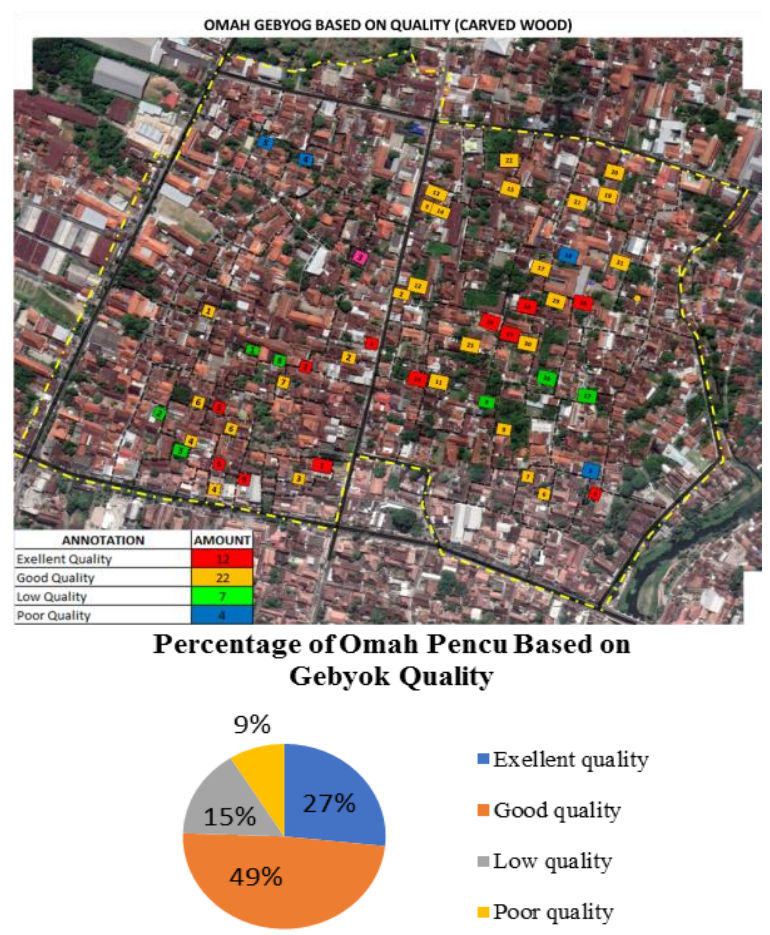

Figure 8 Mapping and Percentage Typology Omah Pencu based on Gebyok Quality

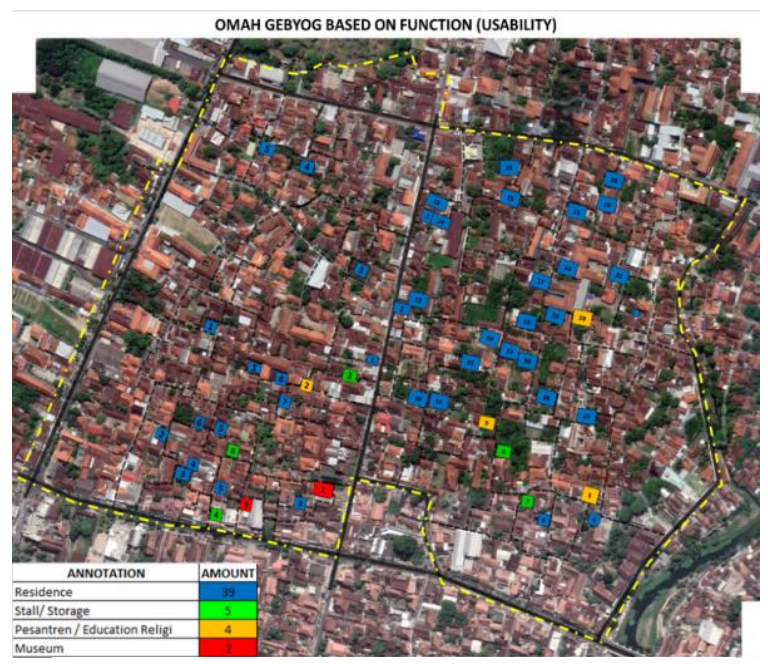

Percentage of Omah Pencu Based on Usability

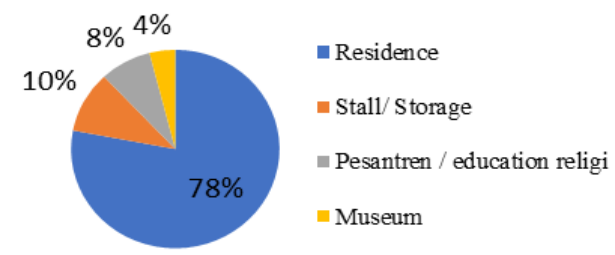

Figure 7 Mapping and Percentage Typology Omah Pencu based on Usability

Omah Pencu shows the uniqueness of tangible \& intangible assets. These include spatial morphology, architectural forms, structures, detailed ornamental gebyog, which is an essential basis of preserving cultural heritage (Suprapti et al., 2019; Umar et al., 2019). They also show intangible - cultural values. They contribute to the distinctive architectural character, which has been promoted as the identity of Kudus city. Currently, Omah Pencu is facing the threat of antique objects hunting by domestic and foreign collectors. For protecting cultural heritage, data collection using digital technology is needed. According to Noardo (2018), digital documentation is a fundamental requirement for the preservation, promotion, and education of cultural heritage buildings. From the intangible side, the existence of the community of Gusjigang has an important role and a unique and incomparable society. It shows the living heritage sustainability in the historic area of Kudus Kulon. This result is following the opinions of Bonacchi \& Krzyzanska (2019), Havinga et al. (2019), Seduikyte et al. (2018), and also Wikantari (1999).

\section{Conclusion}

This mapping finds the vital data on the condition of the building's architecture, including the roof's shape dominated by joglo pencu roof shape, which is referred 


\section{TEKNIK, 41 (3), 2020, 209}

to as its authenticity. Condition of the spatial layout indicates its genuine which is dominated by house contain of dalem, pawon and pekiwan. However many houses are no longer in complete conditions. This is caused some of the building parts have been sold. The building usability strengthens the implementation of the living heritage concept, where $78 \%$ maintain the genuine function as a place to live. Others function as a commercial place and as pesantren. Meanwhile, the quality of maintenance shows that less Omah Pencu has good quality due to maintenance costs.

The results show the significant relationship between tangible and intangible aspects of building preservation effort by the community. A combination of digital mapping and architectural mapping is the way to document the cultural heritage building of Omah Pencu through community participation. It is a significant bottom-up participation in the preservation. Omah Pencu and Gusjigang communities in Kudus Kulon Kudus area are a living heritage phenomenon that must be protected to appreciate the local culture. Mapping the Omah Pencu is the first step to preparing a database that is indispensable for protecting cultural heritage buildings. Towards the preservation of Omah Pencu in the Kudus Kulon historic area needs a comprehensive strategy, management, planning, design, integrated all of the stakeholders that involves tangible and intangible assets supported by digital technology.

\section{Acknowledgment}

We thank the Engineering Faculty of Diponegoro University who funded the research. This research was funded by the RKAT fund of the Faculty of Engineering on the Excellent Research Scheme. As well as the Kudus Kulon community, Kudus Regency Government, Menara Mosque Foundation for their cooperation so that this research can run smoothly.

\section{Glossary}

1. Alun-alun : City traditional square

2. Dalem : The main building of Omah Pencu is a place to facilitate a daily life of family-like sleeping, eating, dining, etc

3. Gadri : Dining room

4. Gandhok : Complementary building located near side the main building (Dalem)

5. Gebyog : Ornamental carved wooden wall

6. Gedhongan : The central bedroom

7. Gusjigang : The name of Kudus Kulon community, which has meant

8. Jogan : Hall in the front of Senthong (bedroom)

9. Joglo : The traditional shape of the roof

Pencu which is higher and slightly tapered upwards

10. Jogosatru : Guestroom

11. Latar: : Open yard

12. Limasan : Pyramid roof covers Pawon maligi

13. Omah Pencu building

The wooden traditional house uses Joglo Pencu roof, which spreads in the area of Kudus, Demak \& Jepara

14. Pawon : Building for Kitchen

15. Pekiwan : Well, toilet

16. Pendopo : Pavillion

17. Pesantren : Islamic traditional boarding school

18. Pringgitan : a place to see a shadow puppet show

19. Regol : Gate of fence

20. Santri : Faithfull Muslim/ student of traditional Islamic boarding school

21. Senthong : Bedroom

22. Sisir : Workplace

23. Mosque : Mosque administrators Takmir

\section{References}

Absalyamov, T. (2015). Tatarstan model of public-private partnership in the field of cultural heritage preservation. Procedia-Social and Behavioral Sciences, 188, 214-217.

Arefi, M. (1999). Non-place and placelessness as narratives of loss: Rethinking the notion of place. Journal of Urban Design, 4(2), 179-193.

Baeker, G. (2010). Rediscovering the wealth of places: A municipal cultural planning handbook for Canadian communities. Ontario: Municipal World Incorporated.

Belgiu, M., \& Drăgut, L. (2014). Comparing supervised and unsupervised multiresolution segmentation approaches for extracting buildings from very high resolution imagery. ISPRS Journal of Photogrammetry and Remote Sensing, 96, 67-75.

Blundo, D. S., Ferrari, A. M., del Hoyo, A. F., Riccardi, M. P., \& Muiña, F. E. G. (2018). Improving sustainable cultural heritage restoration work through life cycle assessment based model. Journal of Cultural Heritage, 32, 221-231.

Bonacchi, C., \& Krzyzanska, M. (2019). Digital heritage research re-theorised: ontologies and epistemologies in a world of big data. International 


\section{TEKNIK, 41 (3), 2020, 210}

Journal of Heritage Studies, 1-13.

Budihardjo, E., \& Sujarto, D. (1998). Kota Yang Berkelanjutan. Direktorat Jenderal Pendidikan Tinggi, Departemen Pendidikan Dan Kebudayaan.

Catanese, A. J., \& Snyder, J. C. (1979). Introduction to architecture. New York: McGraw-Hill.

Caust, J., \& Vecco, M. (2017). Is UNESCO World Heritage recognition a blessing or burden? Evidence from developing Asian countries. Journal of Cultural Heritage, 27, 1-9.

Cheng, G., \& Han, J. (2016). A survey on object detection in optical remote sensing images. ISPRS Journal of Photogrammetry and Remote Sensing, 117, 11-28.

De Bernardi, P., Bertello, A., \& Shams, S. M. (2019). Logics Hindering digital transformation in cultural heritage strategic management: An exploratory case study. Tourism Analysis, 24(3), 315-327.

EC--European Commission. (2014). Towards an integrated approach to cultural heritage for Europe. European Commission Com (2014), 477.

Ekarini, D. (2016). Dilema Pelestarian Rumah Adat Kudus. Jurnal Konservasi Cagar Budaya Borobudur, 10(1), 1-15.

Ghilardi, L. (2001). Cultural planning and cultural diversity. Differing Diversities, 123.

Grogan, D., Mercer, C., \& Engwicht, D. (1995). The cultural planning handbook: An essential Australian guide. UK: Routledge.

Havinga, L., Colenbrander, B., \& Schellen, H. (2019). Heritage significance and the identification of attributes to preserve in a sustainable refurbishment. Journal of Cultural Heritage, 43, 282-293.

Hayden, D. (1995). The power of place: urban landscapes as public history. MIT Press. Cambridge, Massachusetts, USA.

Hossain, S., \& Barata, F. T. (2019). Interpretative mapping in cultural heritage context: Looking at the historic settlement of Khan Jahan in Bangladesh. Journal of Cultural Heritage, 3, 297-304.

La Frenierre, J. (2008). Mapping heritage: A participatory technique for identifying tangible and intangible cultural heritage. The International Journal of the Inclusive Museum, 1(1), 97-104.

Lillesand, T., Kiefer, R. W., \& Chipman, J. (2014). Remote sensing and image interpretation. USA: John Wiley \& Sons.

Mercer, C. (2002). Towards cultural citizenship: Tools for cultural policy and development. Available at SSRN 2153304. https://ssrn.com/abstract $=2153304$

Mercer, C. (2006). Cultural planning for urban development and creative cities. Australia: SelfPublished Manuscript.

Moneo, R. (1978). On typology. Oppositions 13.

Noardo, F. (2018). Architectural heritage semantic 3D documentation in multi-scale standard maps. Journal of Cultural Heritage, 32, 156-165.

Oikonomopoulou, E., Delegou, E. T., Sayas, J., \& Moropoulou, A. (2017). An innovative approach to the protection of cultural heritage: The case of cultural routes in Chios Island, Greece. Journal of Archaeological Science: Reports, 14, 742-757.

Poulios, I. (2010). Moving beyond a values-based approach to heritage conservation. Conservation and Management of Archaeological Sites, 12(2), 170-185.

Poulios, I. (2014). Discussing strategy in heritage conservation: living heritage approach as an example of strategic innovation. Journal of Cultural Heritage Management and Sustainable Development, 4(1), 16-34.

Prompayuk, S., \& Chairattananon, P. (2016). Preservation of cultural heritage community: Cases of Thailand and developed countries. Procedia-Social and Behavioral Sciences, 234, 239-243.

Ragusa, A. (2017). Cultural Heritage in a Comparative Approach: In the Name of Aphrodite. UK: Cambridge Scholars Publishing.

Rapoport, A. (1997). Theory in Environment Behavior Studies. In Handbook of Japan-United States Environment-Behavior Research (pp. 399-421). Springer.

Rashid, M. S. A. (2015). Understanding the Past for a Sustainable Future: Cultural mapping of Malay heritage. Procedia-Social and Behavioral Sciences, 170, 10-17.

Rasyidi, R. A., \& Amiuza, C. B. (2017). Semiotika Arsistektur Rumah Adat Kudus Joglo Pencu. Jurnal Mahasiswa Jurusan Arsitektur, 5(3).

Roesmanto, T. (2002). A Study of Traditional House of Northern Central Java-A Case Study of Demak and Jepara. Journal of Asian Architecture and Building Engineering, 1(2), 219-226.

Salamak, M., \& Fross, K. (2016). Bridges in Urban Planning and Architectural Culture. Procedia Engineering, 161, 207-212.

Sardjono, A. B. (2009). Tata ruang rumah tradisional kudus. Jurnal Arsitektur. UNDIP

Sardjono, A. B., Hardiman, G., \& Prianto, E. (2016). Characteristics of traditional houses in the old town of Kudus City, Indonesia. International Journal of Scientific and Research Publication, 109-118.

Seduikyte, L., Grazuleviciute-Vileniske, I., Kvasova, O., \& Strasinskaite, E. (2018). Knowledge transfer in sustainable management of heritage buildings. Case of Lithuania and Cyprus. Sustainable Cities and Society, 40, 66-74.

Stapleton, L., O'Neill, B., Cronin, K., McInerney, P., Hendrick, M., \& Dalton, E. (2019). A SemiAutomated Systems Architecture for Cultural 


\section{TEKNIK, 41 (3), 2020, 211}

Heritage: Sustainable Solutions for Digitising Cultural Heritage. IFAC-PapersOnLine, 52(25), 562-567.

Suprapti, A., BudiSardjono, A., Rochma, H. A., \& Yasmina, N. F. (2014). The Tradition of Living of Muslim Community Kuduskulon. Journal of Social Sciences, 10(2), 63-73.

Suprapti, A., Kim, S., Pandelaki, E. E., \& Firmandhani, S. W. (2018). a Spatial Dialogue of Heritage Village Between Kauman in Semarang and Seochon in Seoul Toward Preservation Development. Journal of Architecture and Urbanism, 42(1), 16-23.

Suprapti, A., Kistanto, N. H., Pandelaki, E. E., \& Indrosaptono, D. (2017). Control of spatial protection in Kauman Semarang. Journal of Architecture and Urbanism, 41(4), 268-277.

Suprapti, A., Sardjono, A. B., Indriastjario, I., \& Pandelaki, E. E. (2019). The spatial concepts of cultural heritage village toward a tourism development; a case study of Kadilangu Demak Indonesia. Journal of Architecture and Urbanism.

Theresia, J. (2013). Studi Tata Ruang Dalam Rumah Adat Kudus. Intra, 1(1), 1-10.

Trancik, R. (1986). Finding lost space: theories of urban design. USA: John Wiley \& Sons.

TUNÇBAŞ, A. (2006). The dialogue of type and model in architecture. Middle east technical university.

Umar, G. K., Yusuf, D. A., Ahmed, A., \& Usman, A. M. (2019). The practice of hausa traditional architecture: towards conservation and restoration of spatial morphology and techniques. Scientific African, 5, e00142.

Wijaya, A., Sugardiman Budiharto, R. A., Tosiani, A., Murdiyarso, D., \& Verchot, L. V. (2015). Assessment of Large Scale Land Cover Change Classifications and Drivers of Deforestation in Indonesia. ISPRS - International Archives of the Photogrammetry, Remote Sensing and Spatial Information Sciences, XL-7/W3, 557-562.

Wikantari, R. R. (1999). A Study on Possible Sustainability of Wooden Traditional Houses through Examination of Residents' Own Evaluation and Intention-The Case of an Historic Area of Kudus, Indonesia. Papers on City Planning, 34, 325-330.

Wikantari, R. R. (2001). The Sustainability of Historic Environment Composed of Wooden Traditional Houses in the City of Java. Doctoral dissertation. Osaka University.

Wikantari, R. R., \& Narumi, K. (1999). Architectural characteristics and the altering tendency of traditional housing group of kudus, indonesia. Journal of Architecture and Planning (Transactions of AIJ), 64(518), 213-221.

Wikantari, R. R., \& Narumi, K. (2001). Prospect of public alley and shared-passage in the historic area of kudus, indonesia, based on the residents'evaluation. Journal of Architecture and Planning (Transactions of AIJ), 66(545), 197-205. 